\section{Dr. Robert Chambers}

Robert Chambers, perhaps the most distinguished figure in the field of experimental cytology, died recently at the age of seventy-five. Of Canadian parentage, he was born in Turkey, where his early years were spent in fascinating and, at times, exciting surroundings. As a young man he graduated at Queen's University, Ontario, and after a period spent in Richard Hertwig's laboratory at Munich, he held teaching and research posts at Cornell and elsewhere. In 1928, he was elected to a research professorship at Now York University, Washington Square; this post he held until his retirement.

Chambers was largely responsible for the development of micro-dissection as a means of investigating the properties of living cells. He was a brilliant technician; to watch his control of a needle or pipette was an inspiration in itself, and much of our knowledge of the processes of fertilization and cleavage of an egg we owe either directly to him or to the enthusiasm which he inspired in others. Not the least of the lessons which he taught was modesty when an experiment went well, and absence of impatience or depression when things went wrong. $\mathrm{H} \theta$ was the author of a very large number of papers, all characterized by their conciseness and clarity of style. Nearly-but perhaps not quite-all his conclusions have been substantiated by the use of techniques much more elaborate than his own.

During the inter-War years Chambers travelled extensively in Europe and made many friends. His handsome features, lit by a characteristically jovial smile, made him a welcome visitor to any laboratory ; within a fow days, he became "Robert" and remained so to young and old alike. For the best part of a generation he and his wife, Bertha, kept open house at their home in Woods Hole or New York. They had the supreme gift of welding a heterogeneous mixture of individuals into a happy gathering free from the strain of soientific research and the troubles of the outside world.

Superficially casual in the affairs of everyday life, Robert's scientific vision was remarkably acute and he pursued his ends tenaciously and unselfishly. $\mathrm{He}$ founded and was editor of a journal (Protoplasma), and he started centres of informal discussion which grew into well-organized and successful societies. $\mathrm{He}$ received many honours, but among these the affection of his friends and their respect for his scientific work must have ranked highly. Perhaps his most endearing and characteristic quality was his ability to remain young and-superficially at least-carefree. There can be fow biologists of his own generation to whom his death did not bring a sense of personal loss, and younger cytologists will be among the first to acknowledge the lasting value of his scientific work.

\section{J. Gray}

\section{Prof. Jean Giaja}

Brologists everywhere will learn with regret of the sudden death in Belgrade on October 1 of Prof. Jean Giaja, otherwise Ivan Djaja, which occurred during a symposium on hypothermia, of which he was president. The symposium was being held in connexion with the fifteenth International Congress of Military Medicine and Pharmacy. Physiologists and medical men from many lands had gathered to honour Prof. Giaja and to discuss recent advances in the study of hypothermia, a subject in which he was an authority and had been a pioneer.

Giaja was born in Dubrovnik on August 21, 1884. His father was the skipper of a four-masted barque which sailed the oceans, so that young Giaja was often left with his mother, who was a Frenchwoman and who influenced him greatly and provided a rich cultural background. He graduated from the University of Belgrade and, after a year at Rouen, moved to Paris, where he spent six years doing physiological research under Prof. Dastré. He was awarded the degree of doctor of biological sciences at the Sorbonne. Then, in 1910, he was appointed professor of physiology in the University of Belgrade. There he remained until his death.

During the past fifty-two years Prof. Giaja had published many original articles and reviews. Between 1906 and 1920 he studied the enzymic breakdown of glucosides and carbohydrates in mammals, birds, fish, invertebrate marine animals and yeasts. This led to investigations of energy intake and exponditure by yeasts, and by poikilothermic, homœothermic and hibernating animals. His results enabled him to draw important conclusions about the regulation of heat production and maintenance of body temperature in birds and mammals. As long ago as 1930 Giaja began to study mammals with reduced body temperatures. He was the first to use the rat for this purpose and to show the protective action of hypothermia in a variety of adverse conditions including lack of oxygen. Twenty years passed before the subject of hypothermia became fashionable as a result of its application to cardiac surgery in 1950. By then a firm physiological basis for its use had been laid by Prof. Giaja.

Although nominally he retired three years ago, Prof. Giaja continued active research until the last. One of his recent articles on "Survival of the Heart following Deep Hypothermia" was recently pub. lished in Nature $(178,1286 ; 1956)$. He was a member of the Serbian and French Academies of Sciences, of several Yugoslavian and French scientific societies and of the Légion d'Honneur. Among his hobbies were gardening, boats, music, reading and travel.

Prof. Giaja had a charming personality and inspired admiration and affection in his students, his colleagues and his numerous friends among scientists overseas. $\mathrm{He}$ is survived by a daughter and by his second wife, who had worked with him for many years.

AUdrey SMITH

\section{Prof. Antonino Mura}

The untimely death of Antonino Mura, which occurred on July 24, near Milan, deprived physics of a dedicated student. He was born in Florence on March 19, 1916, and after attending the Scuola Normale Superiore in Pisa, obtained his doctor's degree in physics in 1938. Of the nineteen years since then, five were spent with the army during the War, and eight were clouded by the disease that eventually killed him. The remaining years were wholly dedicated to teaching and research at the University of Milan, where Mura contributed so much to re-establishing the academic and scientific activities of the Department of Physics after the Second World War.

Notwithstanding the odds against him, Mura continued to perform remarkable research work in the field of cosmic-ray physics. $\mathrm{He}$ started in 1945 
studying the extensive (Auger) showers, and the properties of their penetrating component. Soon afterwards, he developed the cloud chambers which were to be successfully operated at the Alpine laboratory of Testa Grigia to investigate the characteristics of the nuclear disintegrations induced by cosmic rays: Mura and his co-workers determined the strong nuclear properties of the 'shower' particles emitted from the disintegrations. This research, and later work on the production of neutral pions and on the development of the nucleon cascade, shared with other investigations carried out in the same years in different countries the merit of bringing about the present understanding of the phenomenological aspects of the cosmic radiation: namely, that the extensive, the penetrating and the mixed showers are but different offspring of the high-energy nucleon-nucleon collision, the most catastrophic phenomenon of Nature.

It was with the intention of collecting information relevant to the behaviour of high-energy particles that he and his colleagues engaged in the study of phenomena underground. They demonstrated the groundlessness of reports from other investigators suggesting that the muons might give rise to previously unknown sub-atomic particles : the assumption of non-electromagnetic interaction properties of the muons could thus be discarded.
After this work, Mura was no longer able to participate directly in the experimental activity : in his last years his ailing body prevented him from contributing more than advice, criticism and interpretation of results. His interest in physics remained, however, unabated; and to the very end of his life he continued to discuss scientific subjects either in letters or with gatherings of his collaborators around his hospital bed.

The association of most of Mura's work with such an exacting and delicate instrument as the cloud chamber was not casual. He was at heart a respectful student of Nature, and elected to depend on a research tool presenting a straightforward kind of evidence of Nature's ways. His particular excellence as a physicist lay in his relentlessly critical mind, striving to uncover whatever truth, if any, might be hidden under uncritically accepted, misleading or exaggerated statements.

This earnest approach to the object of scientific research did not prevent him from being good. humoured and witty; and this indeed was his prevailing mood in performing his duties and in his contacts with people. He made an ideal partner in team-work, because he sincerely believed that everyone tries always to do his best. He never complained of his fate, of which he must have been deeply aware.

\section{NEWS and VIEWS}

\section{Artificial Meteors}

IT is reported from the United States that in an experiment devised by the U.S. Air Force Research Station at Cambridge, Massachusetts, artificial meteors in the form of aluminium pellets were released by an Aerobee rocket at an altitude of 54 miles over New Mexico on October 16. It is probable that some of the meteors, which were ejected from the rocket by means of shaped charges of explosive, may have achieved speeds in excess of the velocity of escape from the Earth's gravita. tional field. A photograph taken with a Baker Super-Schmidt meteor camera is said to have shown one of these meteors travelling at a speed greater than 33,000 miles per hour, with a brightness of stellar magnitude -2. Observations of the temperature (luminosity) and rate of vaporization of artificial meteors, the composition and mass of which are known, are likely to be of use for determining the density of the Earth's atmosphere at great heights. Radar observations of the ionized trail of such meteors may also be expected to throw light on processes occurring in the ionosphere.

Electrical Engineering at The Queen's University,
Belfast : Belfast :

Prof. P. L. Burns, who retires from the chair of electrical engineering in The Queen's University of Belfast at the close of the present session, received his engineering education at the University of Manehester, where, during the First World War, he was associated with Lord Rutherford in the problem of the detection of submarines. His practical training was obtained in the then British Westinghouse Co. at Trafford Park, Manchester. $\mathrm{He}$ entered the teaching profession in 1918, being successively in

charge of the electrical engineering departments at Hull Technical College and at Rutherford College, Newcastle upon Tyne, before being appointed in 1924 to the position of head of the Department of Electrical Engineering and Physics of the Belfast College of Technology and extra-mural professor of electrical engineering in The Queen's University of Belfast. This position he held until 1955 when, with the formation of the Joint Authority for Higher Technological Studies, he became the first holder of the university chair in his subject, being still associated with the Belfast College of Technology as director of higher studies in electrical engineering.

Prof. Burns's tenure of the ehair has been marked by steady developments in both the University and the Technical College sides of the department, in all of which his skill as a teacher found full scope. His interest in the students has not, however, been confined to their academic studies, for he has interested himself in all their activities. For a considerable period during and after the War he commanded the Signals Unit of the Senior Training Corps, for the formation of which he had been responsible. He was elected president of the University Rugby Club, and his cheerful and enthusiastic figure is a familiar sight on the touch-line at all university matches. Prof. Burns carries into his retirement the best wishes of his colleagues and of the long line of students who came under his influence, many of whom now hold positions of high responsibility in industry.

\section{Dr. J. C. West}

Dr. J. C. WeST, who has been appointed to succeed Prof. P. L. Burns, entered the Department of Electrical Engineering at the University of Manchester in October 1940, and graduated 